\title{
Effects of conjugated linoleic acid on proliferation and differentiation of bovine intramuscular preadipocyte in vitro
}

\author{
Rong Wan ${ }^{\mathrm{a}, *}$, Qingxiang Meng ${ }^{\mathrm{b}}$, Zhou Zhenming ${ }^{\mathrm{b}}$, Wu hao ${ }^{\mathrm{b}}$ \\ ${ }^{a}$ College of Agriculture and Food Engineering, Baise University, Zhongshan Second Road 21 Number, Baise \\ 533000, PR. China \\ ${ }^{b}$ Laboratory of Animal Nutrition, Beef Cattle Research Center, College of Animal Science and Technology, \\ China Agricultural University, Beijing 100193, PR. China
}

\begin{abstract}
Conjugated linoleic acid (CLA), a mixture of isomers of linoleic acid, has previously been shown to be able to increase intramuscular fat content in vivo and stimulate adipogenesis in intramuscular preadipocytes in vitro in pig. Unfortunately, there is little data to evaluate the effect of CLA on proliferation and differentiation of bovine intramuscular preadipocytes. This study investigated the regulation by CLA in proliferation and differentiation of bovine intramuscular preadipocytes. The results demonstrated that CLA significantly induced the expression of PPAR $\gamma$ and $\mathrm{C} / \mathrm{EBP} \alpha \mathrm{mRNA}$ of bovine intramuscular preadipocytes as well as the accumulation of lipid in cultured intramuscular preadipocytes. Additionally, CLA significantly decreased the cell proportion of phase $\mathrm{G} 0 / \mathrm{G} 1$, and remarkably increased the proportion of phase S+G2/M. Collectively, these results suggest that CLA promotes bovine intramuscular preadipocyte proliferation and differentiation.
\end{abstract}

KEY WORDS: Luxi yellow cattle, intramuscular preadipocyte, proliferation, differentiation, conjugated linoleic acid

\section{Introduction}

Intramuscular fat (Marbling) is indeed a true adipose tissue embedded within a connective tissue matrix in close proximity to a blood capillary network, primarily stored within the intramuscular adipocytes. It is one of the main factors used to determine beef quality grade in the United States (USDA, 1997), Japan (JMGA, 1988), and Korea. Insufficient intramuscular adipose and excessive subcutaneous adipose are significant beef quality challenges (Smith et al., 2006; Barnes et al., 2012). Regarding the marbling adipogenesis in the beef, the major processes involved are the proliferation of preadipocytes and their differentiation into mature adipocytes.

Conjugated linoleic acid (CLA) is a collective term for a group of octadecadienoic acids that are geometric and positional conjugated isomers of linoleic acid (Pariza et al., 2001). It is naturally generated in the rumen of ruminant animals by fermentative bacteria, which isomerizes linoleic acid into CLA. Ruminants also synthesize CLA via $\square 9$-desaturase of trans-11 octadecanoic acid (Griinari et al., 2000; Gruffat et al., 2008). It has been clearly demonstrated that treatment with CLA isomers decreases the proliferation and differentiation of murine

*Corresponding author. Tel.: +860776 2860816.

E-mail address: qingfengyimeng118@126.com (Rong Wan). 
and human preadipocytes in vitro (Brodie et al., 1999; Evans et al., 2000; Satory and Smith, 1999; Brown et al., 2001; Brown et al, 2003; Yeganeh et al., 2016; Yeganeh et al., 2017). However, CLA has been reported to increase intramuscular fat deposition while decrease subcutaneous fat in pigs (Dugan et al., 1997; Wiegand et al., 2002; Zhou et al., 2007). But CLA fails to inhibit the proliferation and differentiation of pig preadipocyte(Ding et al., 2000; McNeel and Mersmann, 2003). Additionally, Schmidt et al. (Schmidt et al., 2016) found that cultured adipocytes derived from dairy cows respond differently to CLA than those derived from monogastric species. These effects appear to be mediated by 2 isomers of CLA, and the 2 biologically active isomers are the CLA cis-9, trans-11 and the CLA trans-10, cis-12. However, little data is available regarding the regulation of bovine intramuscular preadipocyte proliferation and differentiation by CLA. The purpose of this study, therefore, is to examine the effect of CLA on proliferation and differentiation of intramuscular preadipocytes from Chinese Luxi steers.

\section{Materials and methods}

\subsection{Materials}

Dulbecco's modified Eagle's medium (DMEM) and Dulbecco's Phosphate-Buffered Saline (DPBS) were purchased from Gibco (Grand Island, N.Y.). Bovine insulin, dexamethasone, Collagenase, HEPES (powder), and conjugated linoleic acid [a mixture of CLA isomers consisting of cis-9, trans-11 (50\%), cis-12, trans-10 (40\%), and cis-10, cis-12 (10\%)] were bought from Sigma-Aldrich Fine Chemical (St. Louis, MO, USA). Fetal bovine serum (FBS) was a product of PAA Company (Austria). All other compounds were from Beijing Chemical Reagent Company (China).

\subsection{Animal}

All procedures involving animals were conducted under the approval of the Baise University, College of Agriculture and Food Engineering Animal Care and Use Committee. Three Luxi Yellow steers (18 months of age) were used in this study and approved by AEC. The cattle were fed at the National Institute of Animal Industry.

\subsection{Cell isolation and culture}

Details of tissue collection, homologous preadipocyte preparation, and the bovine intramuscular preadipocyte culturing were described as previously outlined (Aso et al., 1995). All material preparations were performed under aseptic condition, and the whole procedure was operated between the sixth and ninth passage, and the cell was cultured in a $5 \% \mathrm{CO}_{2}$ humidified chamber at $37 \square$.

\subsection{Assessment of cell proliferation}

Bovine intramuscular preadipocytes treated with CLA were analyzed by flow cytometry. Briefly, cells were seeded in T-25 flask at the density of $10^{4}$ cells $/ \mathrm{cm}^{2}$ in DMEM containing $100 \mathrm{U} / \mathrm{mL}$ penicillin, $100 \mu \mathrm{g} / \mathrm{mL}$ streptomycin, $15 \mathrm{mM}$ HEPES and 10\% FBS (growth medium) supplemented with CLA at the concentration of 0 $\mu \mathrm{M}, 50 \mu \mathrm{M}, 100 \mu \mathrm{M}$, and $150 \mu \mathrm{M}$. Media were changed every 2 days. 4 days later, the treated cells were collected and suspended in $15-\mathrm{mL}$ sterile tubes, and then counted in hemocytometer to determine cell number. Subsequently, the cells were permeabilized with $0.1 \%$ Triton X-100 in DPBS for 30 min at room temperature. 
73 Permeabilized cells were treated with $40 \mu \mathrm{g}$ of RNAse/mL and then the DNA was immediately labeled with 100

$74 \mu \mathrm{g} / \mathrm{mL}$ propidium iodide $(\mathrm{PI}) / \mathrm{mL}$ before analysis.

\subsection{Oil red $O$ staining}

Cells were stained with oil red $\mathrm{O}$ to make accumulated triacylglycerols visible. Briefly, cells were rinsed three times in DPBS and then fixed in $10 \%(\mathrm{v} / \mathrm{v})$ formaldehyde for $1 \mathrm{~h}$. Subsequently, the fixed cells were rapidly rinsed with isopropanol. In the end, $0.5 \%$ oil red $\mathrm{O}$ in isopropanol was added to the cells for $1 \mathrm{~h}$, finally lipid droplets were stained with red color so that they could be visible.

\subsection{Assay of preadipocyte differentiation}

When bovine intramuscular preadipocytes were confluent (referred to day 0), the cells would be further cultured for 2 days in DMEM with mixture of $10 \mu \mathrm{g} / \mathrm{mL}$ insulin, $0.25 \mu \mathrm{mol} / \mathrm{L}$ dexamethasone, and 5\% FBS (differentiation medium), and subsequently in fresh differentiation medium at different concentrations of CLA(0 $\mu \mathrm{M}, 50 \mu \mathrm{M}, 100 \mu \mathrm{M}$, and $150 \mu \mathrm{M}$ ). At day 6, intracytoplasmic lipid content was determined using modified Ramirez-Zacarias' method (Ramirez-Zacarias et al., 1992). $1.5 \mathrm{~mL}$ of isopropanol was added to the stained 24-well culture plates to identify the extent of preadipocyte differentiation,.Oil red $\mathrm{O}$ stained intracytoplasmic lipid was quantified by measuring its absorbance at $510 \mathrm{~nm}$ on spectrophotometer.

In addition, this study was designed to investigate the regulation of individual medium components to bovine intramuscular preadipocyte differentiation. Treatment medium was consisted of base medium supplemented

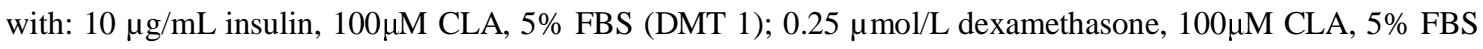
(DMT 2); $10 \mu \mathrm{g} / \mathrm{mL}$ insulin, $0.25 \mu \mathrm{mol} / \mathrm{L}$ dexamethasone, 5\% FBS (DMT 3); $10 \mu \mathrm{g} / \mathrm{mL}$ insulin, $0.25 \mu \mathrm{mol} / \mathrm{L}$

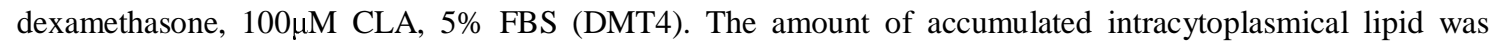
measured after 6-day differentiation.

\section{7. $R N A$ isolation and reverse transcription-polymerase chain reaction (RT-PCR)}

Briefly, the housekeeping gene GAPDH was used as internal control for the identification of targeted mRNA levels. PCR was performed in 1 cycle for $5 \mathrm{~min}$ at $94 \square$, several cycles of denaturation for $30 \mathrm{~s}$ at $94 \square$ (details below), annealing at decreasing temperatures with increasing cycle numbers for $30 \mathrm{~s}$ and extension for 1 min (PPAR $\gamma, \mathrm{GAPDH})$ or $40 \mathrm{~s}(\mathrm{C} / \mathrm{EBP} \alpha)$ at $72 \square$. The last extension step was performed for $10 \mathrm{~min}$ at $72 \square$. The primers sequences, annealing temperatures, products sizes and cycle numbers were as follows: (1) For PPAR $\gamma$, forward: 5'-CAGAGATGCCGTTTTGGC-3', reverse: 5'-AGCCGGGGATATTCTTGG-3', annealing at 52 $\square$, product size $900 \mathrm{bp}$ and 35 cycles. (2) For C/EBP $\alpha$, forward: 5'-TGGACAAGAACAGCAACGAG-3', reverse: 5'-TTGTCACTGGTCAGCTCCAG-3', annealing at 58 $\square$, product size 130 bp and 35 cycles. (3) For GAPDH, forward: 5'-ATGCTGGTGCTGAGTATGTG-3', reverse: 5'-GTGTCGCTGTTGAAGTCG-3', annealing at 60ロ, product size $604 \mathrm{bp}$ and 25 cycles. Annealing temperature and cycle numbers were determined by amplification kinetics. Gel electrophoresis with $1 \%(\mathrm{PPAR} \gamma, \mathrm{GAPDH})$ or $2 \%(\mathrm{C} / \mathrm{EBP} \alpha)$ agarose gels was used for PCR products, then stained with ethidium bromide and visualized by UV-transillumination.

\subsection{Statistical analysis}

Data was expressed as least squares means \pm standard error of the mean (SEM), with at least three repeats in each experimental group. Three experimental repeats were performed using BIPs from each animal sample. 
110 Results of cell proliferation and differentiation were analyzed in 1-way analysis of variance (ANOVA) with

111 CLA treatment as the primary analysis factor. And results of various media treatment and RT-PCR were still

112 analyzed in 1-way analysis of variance (ANOVA). Least squares means \pm standard error of the mean (SEM) was

113 used to display the study result. All data was analyzed by using SAS (version 8.0, SAS Institute, Cary, NC).

114 Difference was considered as statistically significant at $\mathrm{P}<0.05$.

\section{3. Results}

116 3.1. Effect of CLA on proliferation of bovine intramuscular preadipocytes

117 To investigate the effect of CLA on the proliferation of bovine intramuscular preadipocytes, the cells were 118 treated with CLA for 4 days, and then collected for analysis by flow cytometry (Fig. 2). The cell proportion of 119 phase G0/G1 decreased significantly $(\mathrm{P}<0.05)$ by $9.2 \%$ in $100 \mu \mathrm{M}$ CLA (Fig. 1; Table 1), and the proportion of 120 phase $\mathrm{S}+\mathrm{G} 2 / \mathrm{M}$ remarkably $(\mathrm{P}<0.05)$ increased by $18.1 \%$ compared with the control group $(0 \mu \mathrm{M}$ CLA) (Fig. 1; 121 Table 1). However, concentrations of $50 \mu \mathrm{M}$ or $150 \mu \mathrm{M}$ CLA supplement had no significant effect on bovine 122 intramuscular preadipocyte proportion of G0/G1, S, and G2/M phase (Fig. 1; Table 1).

\subsection{Cell morphology and lipid accumulation}

124 To investigate the effect of CLA on the differentiation of bovine intramuscular preadipocytes, 125 intracytoplasmic fat content in the cell which was treated with CLA for 6 days, was determined through 126 measuring intracellular lipid droplets stained with oil red O. After the cells were treated with CLA, significant 127 accumulation of intracellular lipid droplets was observed at day 6 (Fig. 3), and intracellular lipid content tended to increase progressively (Fig. 3). in treatments of 50, 100 and $150 \mu \mathrm{M}$ CLA compared with control group . In addition, the results showed that CLA increased the cytoplasmic fat content of intramuscular preadipocytes in a dose-dependent manner, 1.5, 2.5, and 4 times that of the control group respectively (Fig. 4; Table 2).

3.3. Effect of various media components on the accumulation of intracytoplasmic lipid in bovine intramuscular 132 preadipocytes

133 To determine the effects of various media components on the differentiation of bovine intramuscular 134 preadipocyte, intracytoplasmic lipid content of the treated bovine intramuscular preadipocytes was measured. 135 The combination of CLA, insulin, and dexamethasone resulted in the greatest intracytoplasmic lipid content 136 (DMT4, Fig. 5), whereas the removal of dexamethasone, insulin or CLA reduced intracytoplasmic lipid content 137 by $74 \%, 68 \%$ and $31 \%$ respectively (DMT1, DMT2, DMT3, Fig. 5) compared with DMT4 group (P<0.05).

To further reveal the effect of CLA on the differentiation of bovine intramuscular preadipocytes, the effect of 140 CLA on the expression of key adipogenic transcription factors was examined. The expression of mRNA 141 transcripts for these genes on day 6 after induction is shown in the result (Fig. 6). CLA treatment significantly 142 up-regulated the expression of $\operatorname{PPAR} \gamma$ and $\mathrm{C} / \mathrm{EBP} \alpha$ mRNA of bovine intramuscular preadipocytes compared 
143 with the control (P < 0.05, Fig. 6). Most importantly, the concentration of PPAR $\gamma$ mRNA increased threefold in

144 the CLA-treated cells, whereas the concentration of C/EBP $\alpha$ mRNA doubled (Fig. 6). There was no difference

145 in PPAR $\gamma$ and $\mathrm{C} / \mathrm{EBP} \alpha$ mRNA expression among the CLA-treated groups.

\section{4. Discussion}

147 This study documented the effect of CLA on the proliferation and differentiation of bovine intramuscular 148 preadipocytes in vitro. Several studies have reported that CLA is an effective regulator of body fat accumulation 149 and retention (Pariza et al., 1996; Park et al., 1997; Belury and Kempa-Steczko, 1997; Sisk et al., 1998; Azain, 150 2003; Dugan et al., 2004; Yeganeh et al., 2017). Satory and Smith (Satory and Smith, 1999) found that low 151 levels (1-6 $\mu \mathrm{M})$ of crude mixture of CLA isomers reduced the proliferation of 3T3-L1 preadipocytes. Contrary 152 to these data, Brodie et al. (Brodie et al., 1999) found that 25-100 $\mu \mathrm{M}$ of a crude mixture of CLA isomers 153 inhibited the proliferation of cultures of 3T3-L1 preadipocytes. Additionally, McNeel and Mersmann (McNeel 154 and Mersmann, 2003) also found that $50 \mu \mathrm{M}$ of a mixture of CLA isomers decreased porcine adipocyte growth. 155 However, the current results clearly show that CLA at $100 \mu \mathrm{M}$ significantly decreases the cell proportion of phase G0/G1, and remarkably increases the proportion of phase S+G2/M. Both the proportion of S and G2/M phase refers to the extent of cell proliferation. The above results demonstrate that proliferation of bovine intramuscular preadipocytes is promoted by CLA at appropriate concentration. Interestingly, previous studies indicated that CLA treatment had no effect on porcine intramuscular stromal-vascular cells (Zhou et al., 2007).

160 The divergence of results with these experiments may result from different culture condition, species-specific response, or distinction between clonal and primary preadipocytes (stromal-vascular cells).

A novel aspect of this investigation is the observation that CLA significantly increased intracytoplasmic lipid content of bovine intramuscular preadipocytes in a dose-dependent way, visualized by oil red $\mathrm{O}$ staining.It is demonstrated that culture of mature murine 3T3-L1 adipocytes treated with 20-200 $\mu \mathrm{M}$ of crude mixture of CLA isomers for 2 days has 8\% less lipid compared with control group ( Park et al.,1997).it is also reported subsequently that culture of mature 3T3-L1 adipocytes treated with $100 \mu \mathrm{M}$ of a crude mixture of CLA isomers had 55\% less triglyceride content and 1.8 fold more lipolysis than that of control group ( Park et al.,1999). Additionally, several studies also demonstrate that mixed isomers of CLA reduce triglyceride content in differentiating 3T3-L1 preadipocytes (Park et al., 1999; Evans et al., 2000; Evans et al., 2001). However, differences observed among these investigations may have been due to different species, especially adipose tissue depots. It has been demonstrated that preadipocytes from different depots in rats (Sztalryd et al., 1991; Kirkland et al., 1996), porcines (Hausman and Poulos, 2004; Poulos and Hausman, 2006; Zhou et al., 2007), humans (Wabitsch et al., 1996) become varied in differentiation in vitro under identical condition.

Insulin is known to stimulate adipogenesis of swine (Suryawan et al., 1997). Exclusion of insulin from differentiation media prevented the adipogenesis of ovine preadipocytes. Combination of insulin and DEX is necessary to stimulate lipid filling of adipocytes (Adams, Flint et al.,1996, Ramsay, Rosebrough et al.,2003). Additionally, glucocorticoid is necessary for preadipocytes differentiation, e.g, porcine preadipocytes continuously exposed to a glucocorticoid undergo considerable differentiation (McNeel and Mersmann, 2003). Glucocorticoids play, at physiological concentration, a permissive role of terminal differentiation in confluent Ob1771 mouse preadipocytes (Gaillard et al., 1991) and 3T3-L1 adipocytes (Wu et al., 1996). Our current study also indicates that the combination of CLA, insulin, and dexamethasone lead to the greatest intracytoplasmic 
182 lipid accumulation (DMT4), whereas the removal of dexamethasone, insulin or CLA reduces intracytoplasmic

183 lipid content by 74\%, 68\% and 31\% respectively (DMT1, DMT2, DMT3) compared with DMT4 group. Thus,

184 there are synergetic effects among DEX, insulin, and CLA in enhancing bovine intramuscular preadipocyte

185 differentiation. Both DEX and insulin may act as modulators of preadipocyte differentiation and be essential for

186 adipogenesis in adipocytes.

187 As preadipocytes differentiate, the mRNA concentration of key transcription factors, such as PPAR $\gamma$ and

$188 \mathrm{C} / \mathrm{EBP} \alpha$ is expected to increase accordingly (MacDougald and Lane, 1995; Rosen et al., 2000). Adipocyte

189 differentiation is the result of transcriptional remodeling that leads to the activation of multiple adipocyte-related

190 genes. Transcription factors such as PPAR $\gamma$ and $\mathrm{C} / \mathrm{EBP} \alpha$ are considered to play a crucial role in preadipocyte

191 differentiation and act in concert to generate fully mature adipocytes (Evan et al, 1999; Paul, 2001; Evan et al.,

192 2002; Feve, 2005; Evan and Ormond, 2006; Masaaki et al., 2008). The results of this study are consistent with

193 the finding that, in vivo, the expression of PPAR $\gamma$ mRNA in longissimus muscle is induced by dietary CLA

194 treatment (Meadus et al., 2002). Our data also demonstrates that CLA treatment significantly up-regulate the

195 expression of PPAR $\gamma$ mRNA of bovine intramuscular preadipocytes. The other two studies also support these

196 findings (Zhou et al., 2007; Evans et al., 2001). Since PPAR $\gamma$ activity is regulated by fatty acid ligands

197 (Spiegelman, 1998; Krey et al., 1997; Schoonjans et al., 1996), and the CLA isomers has been reported to be

198 weak agonists of PPAR $\gamma$ (Clement et al., 2002; Yu et al., 2002), we speculate that the CLA isomers might act as

199 agonists of PPAR $\gamma$. Another possible target gene of CLA is C/EBP $\alpha$. C/EBP $\alpha$ is not expressed during

200 proliferation in 3T3-L1 preadipocytes (Umek et al., 1991) but is highly induced by the onset of differentiation in

201 3T3-L1 preadipocytes (Christy et al., 1991). Our results are consistent with the stimulation effect of C/EBP $\alpha$

202 gene expression by CLA treatment on 3T3-L1 preadipocytes. Consequently, our data indicates that there is clear

203 correlation between the accumulation of intracytoplasmic lipid and the expression of PPAR $\gamma$ and C/EBP $\alpha$ 204 mRNA.

205 In conclusion, our data suggests that CLA can promote bovine intramuscular preadipocyte proliferation and 206 differentiation, which provides new perspective on the control of CLA on intramuscular preadipocyte 207 proliferation and differentiation to improve meat quality in beef industry. However, CLA may have different 208 effect on adipogenesis depending on isomer type and concentration, culture condition, and adipose tissue depots.

209 Therefore, detailed in-depth research is required to verify exactly how CLA influence bovine preadipocyte 210 proliferation and differentiation in more specifical perspective.

211 Acknowledgments: The authors wish to thank Jian Ding, Xiaoling Xu and Liping Sun for their assistance 212 during the experiments.

213 Funding: This study was supported by the research funding of Baise University (DC2000002684).

214 Competing Interests: The authors declare they have no conflicts of interest.

215 Data and Material Availability: Data are available from the corresponding author.

216 Author Contributions: Rong Wan: Conceptualization, Methodology, Validation, Formal Analysis, 217 Investigation, Writing-Original Draft, Supervision, Project Administration; Qingxiang Meng: Conceptualization,

218 Resources, Writing-Review \& Editing; Zhou Zhenming: Conceptualization, Methodology, Writing-Review \& 
Editing; Hao Wu: Conceptualization, Writing-Review \& Editing.

\section{References}

Adams, K.S., Flint, D.J., Cryer, A., Vernon R.G. (1996). Regulation of ovine preadipocyte differentiation in vitro. Proc. Nutr. Soci., 55, 25A.

Aso, H., Abe, H., Nakajima, N. Ozutsumi, K., Yamaguchi, T., Takamori, Y., et al. (1995). A preadipocyte clonal line from bovine intramuscular adipose tissue: Nonexpression of GLUT-4 proteion during adipocyte differentiation. Biochemical and Biophysical Research Communications, 213(2), 369-375.

Azain, M.J. (2003). Conjugated linoleic acid and its effects on animal products and health in single-stomached animals. Proc. Nutr. Soc., 62, 319-328.

Barnes, K. M., Winslow, N. R., Shelton, G., Hlusko, K. C., Azain, M. (2012). Effect of dietary conjugated linoleic acid on marbling and intramuscular adipocytes in pork. Journal of Animal Science, 90 (4), 1142-1149.

Belury, M.A., Kempa-Steczko, A. (1997). Conjugated linoleic acid modulates hepatic lipid composition in mice. Lipids, 32, 199-204.

Brodie, A, Manning, V, Ferguson, K, Jewell, D., Hu, C.Y. (1999). Conjugated linoleic acid inhibits differentiation of pre- and post-confluent 3T3-L1 preadipocytes but inhibits cell proliferation only in pre-confluent cells. J. Nutr., 129, 602-606.

Brown, J.M., et al. (2003). Isomer-specific regulation of metabolism and PPAR $\gamma$ signaling by CLA in human preadipocytes. J. Lipid Res., 44, 1287-1300.

Brown, J.M., Evans, M., McIntosh, M. (2001). Linoleic acid partially reverse the suppressive effects of conjugated linoleic acid on preadipocyte triglyceride content. J. Nutr. Biochem., 12, 381-387.

Christy, R.J., Kaestner, K.H., Geiman, D.E., Lane, M.D. (1991). CCAAT/enhancer binding protein gene promoter: binding of nuclear factors during differentiation of 3T3-L1 preadipocytes. Proc. Natl. Acad. Sci., $88,2593-2597$.

Clement, L., et al. (2002). Dietary trans-10, cis-12 conjugated linoleic acid induces hyperinsulinemia and fatty liver in the mouse. J. Lipid Res., 43, 1400-1409.

Ding, S.T., McNeel, R.L., Mersmann, H.J. (2000). Cojugated linoleic acid increases the differentiation of porcine adipocytes in vitro. Nutr. Res., 20, 1569-1580.

Dugan, M.E., Aalhus, J.L., Schaefer, A.L., Kramer, J.K.G. (1997). The effect of conjugated linoleic acid on fat to lean repartitioning and feed conversion in pigs. Can. J. Anim. Sci., 77, 723-725.

Dugan, M.E., Aalhus, J.L., Kramer, J.K. (2004). Conjugated linoleic acid pork research. Am. J. Clin. Nutr., 79, 1212S-1216S.

Evans, M., Geigerman, C., Cook, J., Curtis, L., Kuebler, B., Mclntosh, M. (2000). Conjugated linoleic acid suppresses triglyceride content and induces apoptosis in 3T3-L1 preadipocytes. Lipids, 35, 899-910.

Evans, M., Geigerman, C., Cook, J., Curtis, L., Kuebler, B., McIntosh, M. (2000). Conjugated linoleic acid suppresses triglyceride content and induces apoptosis in 3T3-L1 preadipocytes. Lipids, 35, 899-910.

Evans, M., et al. (2001). Tran-10, cis-12 conjugated linoleic acid reduces triglyceride content while differentially affecting PPAR $\gamma 2$ and ap2 expression in 3T3-11 preadipocytes. Lipids, 36, 1223-1232.

Evan, D. R., et al. (1999). PPAR $\gamma$ is required for the differentiation of adipose tissue in vivo and in vitro. 
Molecular Cell, 4, 611-617.

Evan, D. R., et al. (2002). C/EBP $\alpha$ induces adipogenesis through PPAR $\gamma$ : a unified pathway. Genes \& Development, 16, 22-26.

Evan, D. R. and Ormond, A. M. (2006). Adipocyte differentiation from the inside out. Mol. Cell Biol., 7, 885-896.

Feve, B. (2005). Adipogenesis: cellular and molecular aspects. Best Practice \& Research Clinical Endocrinology \& Metabolism, 19(4), 483-499.

Gaillard, D., Wabitsch, M., Pipy, B., Négrel, R. (1991). Control of terminal differentiation of adipose precursor cells by glucocorticoids. J. Lipid Res., 32, 569-579.

Griinari, J.M., Corl, B.A., Lacy, S.H., Chouinard, P.Y., Nurmela, K.V., Bauman, D.E. (2000). Conjugated linoleic acid is synthesized endogenously in lactating dairy cows by Delta (9)-desaturase. J. Nutr., 130, 2285-2291.

Gruffat, D., Remond, C., Durand, D., Loreau, O., Bauchart, D. (2008). 9cis, 11trans conjugated linoleic acid (CLA) is synthesized and desaturated into conjugated 18:3 in bovine adipose tissues. Animal, 2:4, 645-652.

Hartwell, L.H., Weinert, T.A. (1989). Checkpoints: controls that ensure the order of cell cycle events. Science, 246, 629-634.

Hausman, G.J., Poulos, S. (2004). Recruitment and differentiation of intramuscular preadipocytes in stromal-vascular cell cultures derived from neonatal pig semitendinosus muscle. J. Anim. Sci., 82, 429-437.

JMGA (1988). New beef carcass grading standards. Tokyo, Japan: Japan Meat Grading Association.

Kirkland, J.L., Hollenberg, C.H., Gillon, W.S. (1996). Effects of fat depot site on differentiation-dependent gene expression in rat preadipocytes. Inter. J. Obes., 20 (Suppl. 3), S102-S107.

Krey, G., et al. (1997). Fatty acids, eicosanoids, and hypolipidemic agents identified as ligands of peroxisome proliferators-activated receptors by coactivator-dependent receptor ligand assay. Mol. Endocrinol., 11, 779-791.

MacDougald, O.A., Lane, M.D. (1995). Transcriptional regulation of gene expression during adipocyte differentiation. Annu. Rev. Biochem., 64, 345-373.

Masaaki, T., Le, L. G., Bing, Z., Michael, V. D., Erasmus, O., Stephen, S. M. (2008). Adipogenesis of bovine perimuscular preadipocytes. Biochem. Biophys. Res. Commun., 366, 54-59.

McNeel, R.L., Mersmann, H.J. (2003). Effects of isomers of conjugated linoleic acid on porcine adipocyte growth and differentiation. J. Nutr. Biochem., 14, 266-274.

Meadus, W.J., Maclnnis, R., Dugan, M.E.R. (2002). Prolonged dietary treatment with conjugated linoleic acid stimulates porcine muscle peroxisome proliferators activated receptor $\gamma$ and glutamine fructose aminotransferase gene expression in vivo. J. Mol. Endocrinol., 28, 79-86.

Park, Y., Albright, K., Storkson, J., Liu, W., Cook, M., Pariza, M. (1999). Changes in body composition in mice during feeding and withdrawl of conjugated linoleic acid. Lipids, 34, 243-248.

Park, Y., Storkson, J., Albright, K., Liu, W., Pariza, M. (1999). Evidence that trans-10, cis-12 isomer of conjugated linoleic acid induces body composition changes in mice. Lipids, 34, 235-241.

Pariza, M., Park, Y., Cook, M., Albright, K., Liu, W. (1996). Conjugated linoleic acid reduces body fat. FASEB $J ., 10$, A560. 
Park Y., Albright K.J., Liu W., Storkson J.M., Cook M.E., Pariza M.W. (1997). Effect of conjugated linoleic acid on body composition in mice. Lipids, 32, 853-858.

Pariza, M.W., Park, Y., Cook, M.E. (2001). The biologically active isomers of conjugated linoleic acid. Prog. Lipid Res., 40, 283-298.

Paul, A. G. (2001). The roles of PPARs in adipocyte differentiation. Prog. Lipid Res., 40(4), 269-281.

Poulos, S.P. Hausman, G.J. (2006). A comparison of thiazolidinedione-induced adipogenesis and myogenesis in stromal-vascular cells from subcutaneous adipose tissue or semitendinosus muscle of postnatal pigs. J. Anim. Sci., 84, 1076-1082.

Ramirez-Zacarias, J.L., Castro-Munozledo, F., Kuri-Harcuch, W. (1992). Quantitation of adipose conversion and triglycerides by staining intracytoplasmic lipids with oil red O. Histochemistry, 97, 493-497.

Ramsay, T.G., Rosebrough, R.W. (2003). Hormonal regulation of postnatal chicken preadipocyte differentiation in vitro. Comp. Biochem. Physiol. B., 136, 245-253.

Rosen, E.D., Walkey, C.J., Puigserver, P., Spiegelman, B.M. (2000). Transcriptional regulation of adipogenesis. Genes Dev., 14, 1293-1307.

Satory, D.L., Smith, S.B. (1999). Conjugated linoleic acid inhibits proliferation but stimulates lipid filling of murine 3T3-L1 preadipocytes. J. Nutr., 129, 92-97.

Schmidt, S. E., Thelen, K, M., Raphael, W., Contreras, G. A., Lock, A. L. (2016). 0771 Effects of trans-10, cis-12 conjugated linoleic acid on gene expression and lipid content of adiocytes derived from lactating dairy cows. Journal of Animal Science, 94 (5), 370-371.

Schoonjans, K., et al. (1996). PPAR alpha and PPAR gamma activators direct a distinct tissue-specific transcriptional response via a PPRE in the lipoprotein lipase gene. EMBO J., 15, 5336-5348.

Sisk, M., Azain, M.J., Hausman, D.B. (1998). Effect of conjugated linoleic acid on fat pad weights and cellularity in Sprague-Dawley and Zucker rats. FASEB J., 12, A536.

Smith, G.C., Savell, J.W., Morgan, J.B., Lawrence, T.E. (2006). Executive summary of the 2005 National Beef Quality Audit. National Cattlemen's Beef Association, Centennial, CO.

Spiegelman, B. (1998). PPAR $\gamma$ : adipogenic regulator and thiazolidinedione receptor. Diabetes, 47, 507-514.

Suryawan, A., Swanson, L.V., Hu, C.Y. (1997). Insulin and hydrocortisone, but not triiodothyronine, are required for the differentiation of pig preadipocytes in primary culture. J. Anim. Sci., 75, 105-111.

Sztalryd, C., Azha, S., Reaven, G.M. (1991). Differences in insulin action as a function of original anatomical site of newly differentiated adipocytes obtained in primary culture. J. Clin. Invest., 88, 1629-1635.

Umek, R., Freidman, A., McKnight, S. (1991). CCAAT-enhancer binding protein: a component of a differentiation switch. Science, 251, 288-292.

USDA (1997). Standards for Grades of Carcass Beef. Washington, DC: Agricultural Marketing Service.

Wabitsch, M., et al. (1996). Biological effects of human growth hormone in rat adipocyte precursor cells and newly differentiated adipocytes in primary culture. Metabolism, 45, 34-42.

Wiegand, B.R., Sparks, J.C., Parrish, Jr F.C., Zimmerman, D.R. (2002). Duration of feeding conjugated linoleic acid influences growth performance, carcass traits, and meat quality of finishing barrows. J. Anim. Sci., 80, 637-643.

Wu, Z., Bucher, N.L.R., Farmer, S.F. (1996). Induction of peroxisome proliferators-activated receptor $\gamma$ during the conversion of $3 \mathrm{~T} 3$ fibroblasts into adipocytes is mediated by $\mathrm{C} / \mathrm{EBP} \beta, \mathrm{C} / \mathrm{EBP} \delta$, and glucocorticoids. Mol. 
Cell. Biol., 16, 4128-4136.

Yeganeh, A., Taylor, C. G., Tworek, L., Poole, J., Zahradka, P. (2016). Trans-10, cis-12 conjugated linoleic acid (CLA) interferes with lipid droplet accumulation during 3T3-L1 preadipocyte differentiation. The International Journal of Biochemistry \& Cell Biology, 76, 39-50.

Yeganeh, A., Zahradka, P., Taylor, C. G. (2017). Trans-10, cis-12 conjugated linoleic acid (t10-c12 CLA) treatment and caloric restriction differentially affect adipocyte cell turnover in obese and lean mice. Journal of Nutritional Biochemistry, 49, 123-132.

Yu, Y., Correll, P., Vander Heuvel, J.P. (2002). Conjugated linoleic acid decreases production of pro-inflammatory products in macrophages: evidence for a PPAR gamma-dependent mechanism. Biochim. Biophys. Acta, 1581, 89-99.

Zhou, Xuan, et al. (2007). CLA differently regulates adipogenesis in stromal vascular cells from porcine subcutaneous adipose and skeletal muscle. J. of Lipid Res., 48, 1701-1709.

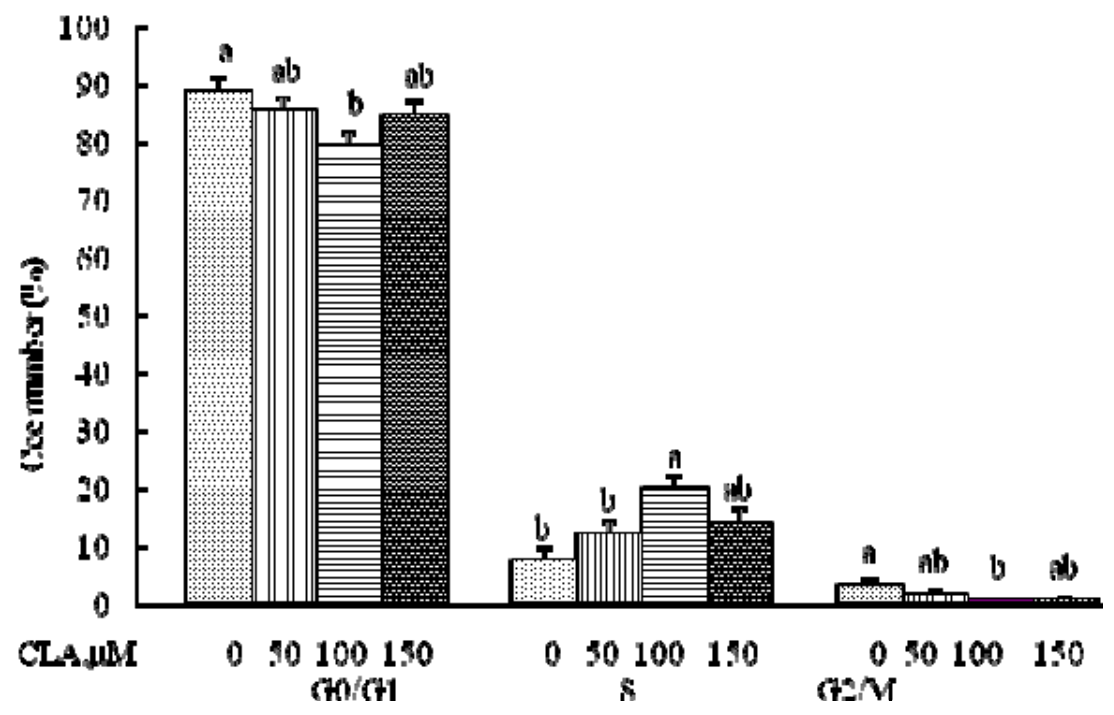

Fig.1. Effect of CLA on the proliferation of bovine intramuscular preadipocytes. The cell cycle is generally considered to be composed of four phases, namely the gap prior to DNA replication (G1), the synthetic phase (S), the gap after DNA (G2) and mitosis (M), and Quiescent or noncycling cells would be considered in G0 (Hartwell et al., 1989). The data was displayed as least squares means \pm SEM $(n=3)$. 

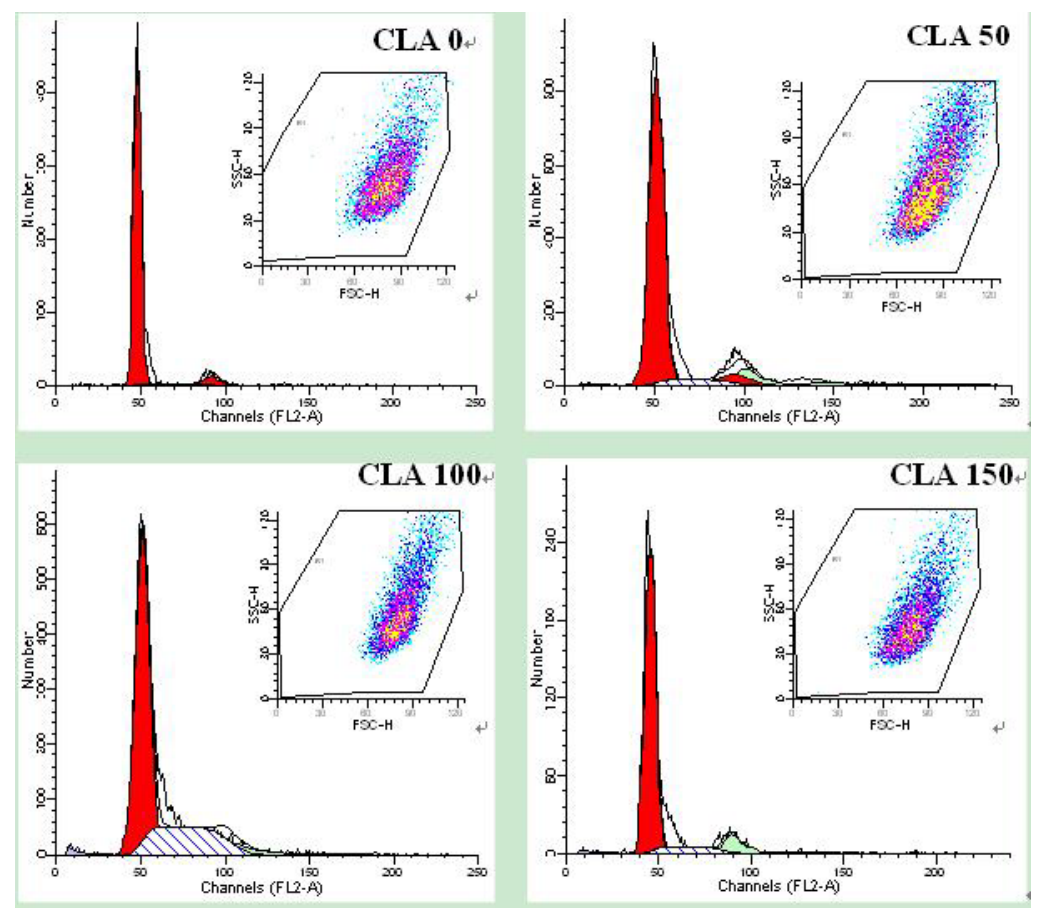

Fig.2. The results of the proliferation of bovine intramuscular preadipocytes were analyzed by flow

359 cytometry.

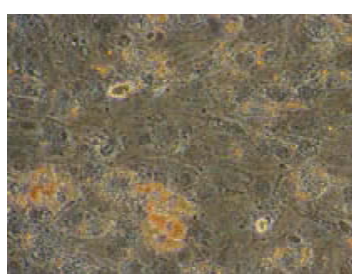

$0 \mu \mathrm{M}$

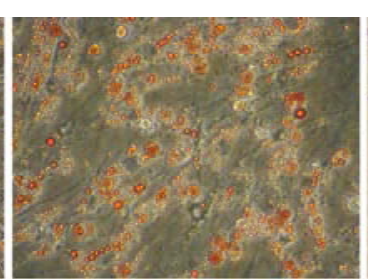

$50 \mu \mathrm{M}$

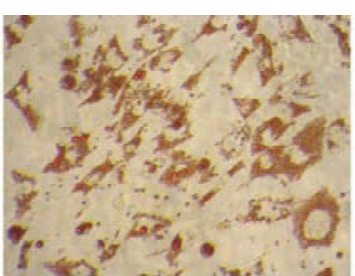

$100 \mu \mathrm{M}$

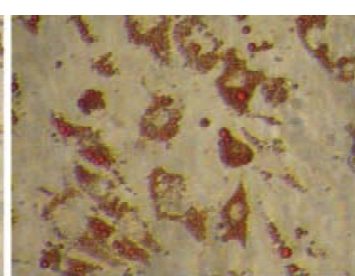

$150 \mu \mathrm{M}$

Fig.3. Morphological changes of bovine intramuscular preadipocyte differentiation stimulated by

CLA. Intracellular lipid droplet was visualized by oil red O staining on day 6. Confluent bovine intramuscular preadipocytes were cultured in differentiation medium with the mix of $0 \mu \mathrm{M}, 50 \mu \mathrm{M}, 100 \mu \mathrm{M}$, and $150 \mu \mathrm{M}$ CLA. 


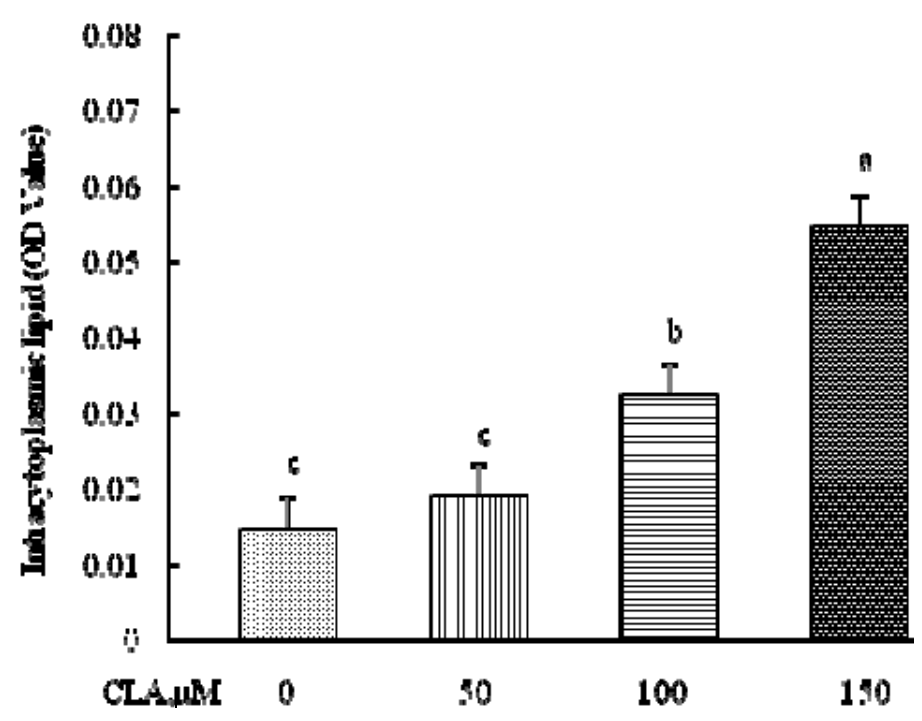

Fig.4. Effect of CLA on accumulation of intracytoplasmic lipid in bovine intramuscular preadipocytes. The cells treated with CLA were always seeded in 24-well plates at the density of $10^{4} \mathrm{cells} / \mathrm{cm}^{2}$, and OD Value was used to collect the number of cells per well. The data was displayed as least squares means \pm SEM $(n=3)$. ${ }^{a}$ ${ }^{b, c}$ Least squares means without a common superscript letter differ $(\mathrm{P}<0.05)$.

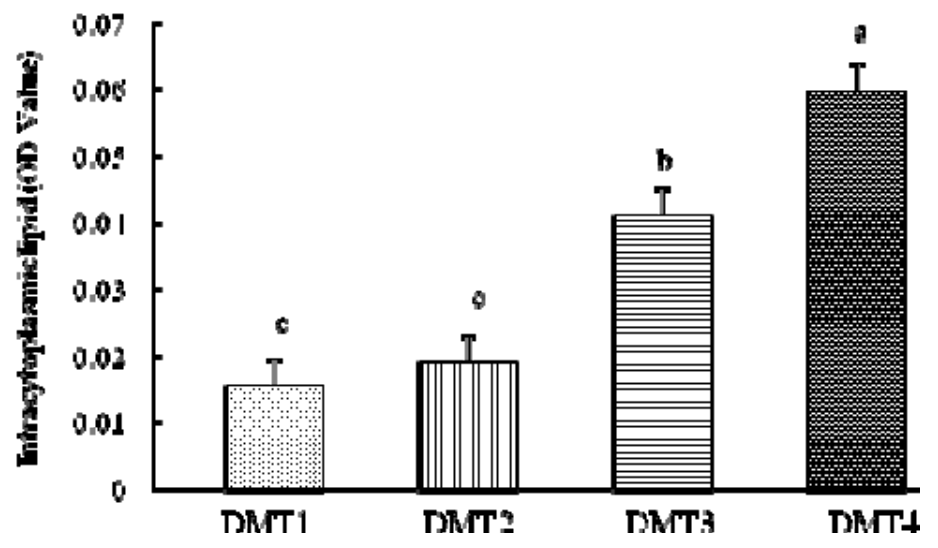

371

Fig.5. Effect of various media components on the accumulation of intracytoplasmic lipid in bovine intramuscular preadipocytes. The treatment of various media components included (1) $10 \mu \mathrm{g} / \mathrm{mL}$ insulin, $100 \mu \mathrm{M}$ CLA, $5 \%$ FBS (DMT 1);(2) $0.25 \mu \mathrm{mol} / \mathrm{L}$ dexamethasone, 100 $\mu \mathrm{M}$ CLA, $5 \%$ FBS (DMT 2); (3) 10 $\mu \mathrm{g} / \mathrm{mL}$ insulin, $0.25 \mu \mathrm{mol} / \mathrm{L}$ dexamethasone, 5\% FBS (DMT 3); (4) $10 \mu \mathrm{g} / \mathrm{mL}$ insulin, $0.25 \mu \mathrm{mol} / \mathrm{L}$

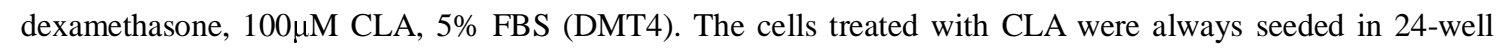
plates at the density of $10^{4}$ cells/cm2, and OD Value was used to collect the number of cells per well. The data are expressed as least squares means $\pm \operatorname{SEM}(n=3)$. ${ }^{a, b, c}$ Least squares means without a common superscript letter differ $(\mathrm{P}<0.05)$. 

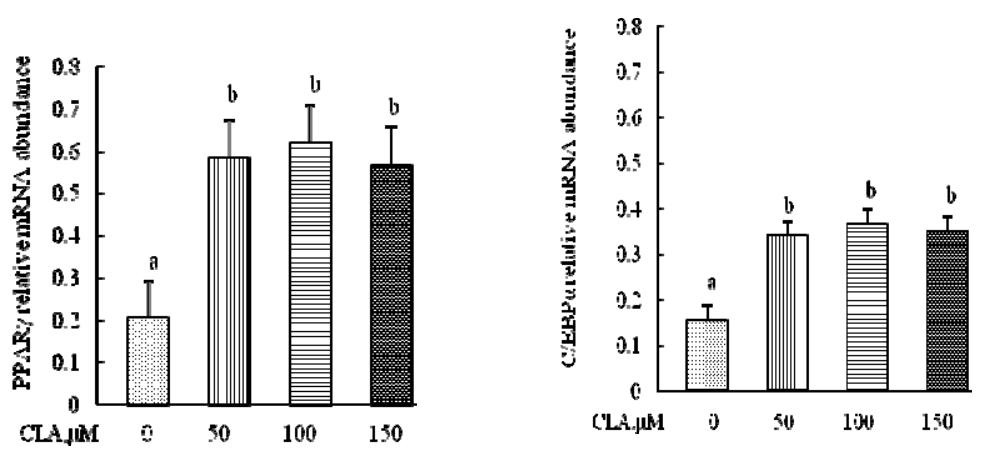

Fig.6. mRNA expression of marker for adipogenesis (PPAR $\gamma$ and C/EBP $\alpha$ ) in differentiated bovine medium with the mix of $0 \mu \mathrm{M}, 50 \mu \mathrm{M}, 100 \mu \mathrm{M}$, and $150 \mu \mathrm{M}$ CLA. RT-PCR was carried out using gene specific primers. The PCR products were run on $1 \%(\mathrm{PPAR} \gamma, \mathrm{GAPDH})$ or $2 \%(\mathrm{C} / \mathrm{EBP} \alpha)$ agarose gels, stained with ethidium bromide and visualized by UV-transillumination. The expression of PPAR $\gamma$ and C/EBP $\alpha$ were normalized by the expression of GAPDH. The data are expressed as least squares means \pm SEM $(n=3)$. ${ }^{a}$ Least squares means without a common superscript letter differ $(\mathrm{P}<0.05)$.

Table1. Effect of CLA on the proliferation of bovine intramuscular ${ }^{1}$

\begin{tabular}{cllll}
\hline Cell & \multicolumn{3}{c}{ CLA, $\mu \mathrm{M}$} \\
\cline { 2 - 5 } number $(\%)$ & 0 & 50 & 100 & 150 \\
G0/G1 & $88.9 \pm 2.39^{\mathrm{a}}$ & $85.8 \pm 2.08^{\mathrm{ab}}$ & $79.7 \pm 2.13^{\mathrm{b}}$ & $84.8 \pm 2.42^{\mathrm{ab}}$ \\
$\mathrm{S}$ & $7.7 \pm 2.22^{\mathrm{b}}$ & $12.4 \pm 2.05^{\mathrm{b}}$ & $20.2 \pm 2.06^{\mathrm{a}}$ & $14.3 \pm 2.17^{\mathrm{ab}}$ \\
& & & & \\
G2/M & $3.4 \pm 1.04^{\mathrm{a}}$ & $1.8 \pm 1.04^{\mathrm{ab}}$ & $0.9 \pm 0.28^{\mathrm{b}}$ & $0.8 \pm 0.23^{\mathrm{ab}}$
\end{tabular}

${ }^{\mathrm{I}}$ Bovine intramuscular preadipocytes were cultured in a growth medium supplemented with $0 \mu \mathrm{M}, 50 \mu \mathrm{M}$, $393100 \mu \mathrm{M}, 150 \mu \mathrm{M}$ CLA for 6 days, and analyzed by flow cytometry. The cells treated with CLA were always 394 seeded in T-25 flask at the density of $10^{4} \mathrm{cells} / \mathrm{cm}^{2}$.

Table2. Effect of dose of CLA on the accumulation of intracytoplasmic lipid in bovine intramuscular 
bioRxiv preprint doi: https://doi.org/10.1101/2021.01.30.428933; this version posted January 31, 2021. The copyright holder for this preprint (which was not certified by peer review) is the author/funder, who has granted bioRxiv a license to display the preprint in perpetuity. It is made available under aCC-BY-ND 4.0 International license.

\section{7 preadipocytes $^{1}$}

\begin{tabular}{ccccc}
\hline Item & \multicolumn{4}{c}{ CLA, $\mu \mathrm{M}$} \\
\cline { 2 - 5 } & 0 & 50 & 100 & 150 \\
OD Value & $0.015 \pm 0.004^{\mathrm{c}}$ & $0.019 \pm 0.004^{\mathrm{c}}$ & $0.032 \pm 0.004^{\mathrm{b}}$ & $0.055 \pm 0.004^{\mathrm{a}}$
\end{tabular}

$398{ }^{1}$ Bovine intramuscular preadipocytes were cultured in a differentiation medium supplemented with $0 \mu \mathrm{M}$,

$39950 \mu \mathrm{M}, 100 \mu \mathrm{M}, 150 \mu \mathrm{M}$ CLA for 6 days, and OD Value was determined to collect the number of cells per well.

400 The cells treated with CLA were always seeded in 24-well plates at the density of $10^{4} \mathrm{cells} / \mathrm{cm}^{2}$. 